\title{
The changing face of union action put to the test by neo-liberal reforms in France
}

\author{
Baptiste Giraud* \\ https://orcid.org/0000-0003-3278-3073
}

Two key features can sum up the French industrial relations system that emerged after the World War II and lasted until the late 1970s. Firstly, French trade unionism differs from its European counterparts by its fragmentation (five nationally recognised representative trade union confederations), a structural weakness in membership numbers, yet an ability to muster considerable collective force. From 1945 to the end of the 1970s, period of economic growth, France was one of the most strikeprone countries in Western Europe. This industrial action stemmed, in particular, from the militant power of the Confédération Générale du Travail (CGT), closely tied to the French Communist Party (PCF), one of France's main political parties at that time. In this economic and political context, trade union struggles subsequently contributed to obtaining social compromises introducing job protection regulations and providing access to a social security system (health insurance, retirement rights followed by unemployment benefits).

Since the mid-1980s, however, French trade unionism has been gripped by a combination of several crises with a steep drop in membership numbers, followed by a political crisis with the electoral collapse of the PCF and the conversion of the French Socialist Party (PS) to liberalism (Rioufreyt, 2019). These political changes have undermined the support and ideological bases that had powered union action up to then. To cap it all, in 1984, the turn to austerity took hold during the François

\footnotetext{
* Université Aix Marseille Univ, CNRS, LEST, Aix-en-Provence, France.
} 
Mitterrand's first term, the first Socialist President of the 5th Republic. This was the beginning to an almost uninterrupted wave of neo-liberal reforms to labour market rules and the welfare system. These reforms were intended to support business competitiveness in a global economy but resulted in the rise of precarious jobs (temporary work, fixed-term contracts) and a softening in redundancy and breach of contract procedures (Signoretto, 2015). At the same time, a series of reforms meant to cut the 'cost' of work and reduce public sector deficits resulted in raising the age of retirement, to streamline the management of the health insurance system and tighten the criteria to access unemployment benefit.

This neo-liberal step-change went hand-in-hand with the development of concertation and bargaining institutions, both in the workplace and at the national level (Béroud and Galvão, 2019). For example, in 2007, the Larcher Act obliged the government to first consult with trade unions and employers' representatives when it wanted to reform labour laws. It offered social partners the option of negotiating an agreement before the legislative process took effect. In doing so, successive governments increasingly sought to bolster the legitimacy of economic and social reforms by claiming responsibility their negotiated nature. This desire also transformed French trade unions by seeking to foster the emergence of a more 'reformist' form of trade unionism more willing to negotiate ongoing reforms rather than contest by collective mobilizations.

These liberal policies are part of a wider transformation of European social models (Andolfatto and Contrepois, 2016). Nevertheless, they have met with strong trade union resistance, especially in the 2000s, marked by a series of periods of protests on a very large scale. This temporary revival of trade union protest could not, however, hide the extent of change in the French trade union landscape and the consequent erosion of its power to mobilize in the long-term. Compared to the 1980s, the intensity of strike activity has clearly declined. This decline is not linear (Vandaele, 2016). During the 2000s, there has been a revival of strike activity and other forms of trade union protests (Béroud et al., 2008). Yet, collective labour disputes experienced a pronounced dip in the 2010s, while liberal labour market and welfare system reforms continued apace.

To emphasis the way in which French trade unions greet the neo-liberal reforms they face, this paper seeks to analyse the structural changes that hinder the growth of trade union action, together with more circumstantial processes that might explain its extent variation. More often than not, the study of contemporary trends of strikes activity focuses on one of its many possible explanatory factors: economic determinants, institutional explanations or organizational variables. I think more useful to draw on the Franzosi's approach taken from his analysis of changes to strike 
action in Italy (Franzosi, 1995). It draws on the different paradigms of strike analysis to reconstruct how economic, political and organisational changes together affect the strategies of union representatives when dealing with neo-liberal reforms. At the same time, this article aims at showing the need not to consider French trade unionism as a category of homogenous actors. On the contrary, neo-liberal reforms make union divisions much visible. After reviewing the meaning of these trade union cleavages, this article sheds light on the new forms that the waves of protest against neo-liberal reforms are taking and questions the persistent limits of the capacity of trade union organizations to prevent their implementation.

French trade unionism facing up to crises (1984-1995)

The switch to neo-liberal policies in France in the 1980s hit the trade union field just when it was facing internal changes. Indeed, the 1970 s were marked by an alliance between the two biggest trade unions, the Confédération Française Démocratique $\mathrm{du}$ Travail (CFDT) and the CGT ${ }^{1}$. This coalition was an extension of the electoral coalition between the Socialist Party and the Communist Party, intended to challenge the monopolization of the political power by the right-wing parties. At this time, the CGT and the CFDT represented almost $80 \%$ of trade union members. So, their coalition helped fuel an unprecedented surge in social conflicts during the 1970s, with frequent mass demonstrations. But, after a fresh defeat of the Left in the 1978 General Election, the CFDT leaders distanced themselves from a model for trade unionism that was deemed overly political. Faced with a falling membership, the CFDT thought it better to separate trade union and partisan struggles to prioritise the search for compromises with the government and employers through collective bargaining. They considered it a way of regaining credibility for trade union activities from an employee perspective. This new rift between the trade unions was an initial hindrance to the growth of union-backed opposition to the austerity policies brought in by the Socialist government in 1984 .

\section{Trade union divisions faced with the liberal turning point}

In response to the economic crisis and mass unemployment in France at the time, the Fabius government adopted wage restraint policies and encouraged greater flex-

1. The French trade union movement is basically split into 5 representative union confederations. The CGT and the CFDT are the two largest unions, followed by Force Ouvrière (FO), the Confédération Générale des Cadres (CFE-CGC) and the Confédération Française des Travailleurs Chrétiens (CFTC). 
ibility into the labour market. Despite these measures the CFDT continued on a more reformist path. The CFDT's leaders actually condemned the old ideology of striking, "which has fallen out of favour as many employees realise that they put increasing pressure on companies that are already struggling to maintain their jobs"2. With rising mass unemployment, changes to the French economy (deindustrialisation and globalisation) coupled with the rapid decline in trade union membership, the leaders of the CFDT thought that French trade unionism had to change its practices. They firstly rallied around the idea that modernising the labour market and welfare system was needed to ensure French businesses were competitive. To their point of view, the time of a collective bargaining based on a rationale of accruing workers' rights was over. Instead, they advocated a more pragmatic negotiating stance based on discussion and mutual concessions. This combined accepting greater flexibility in employment, accounting for new aspirations among employees (e.g. independence at work by adopting more flexible hours) and protecting the most vulnerable workers' interests (jobseekers, those in precarious employment) (Groux and Mouriaux, 1989). Moreover, at the outset of F. Mitterrand's term as President CFDT representatives had sought and secured the development of new procedures for consultation and collective bargaining in companies. In their opinion, this was all the more reason to consider striking only as a last resort. The CFDT banked on its ability to negotiate 'reasonable' compromises to re-establish the legitimacy of its action with employees while positioning itself as a key actor for dialogue with employers and the government.

The CFDT's reformist transformation triggered a sustained period in which the balance of power between French trade unions shifted. To begin with, this further isolated the CGT in protests against the introduction of neo-liberal labour market reforms that it continued to contest, by organizing numerous strikes and mass demonstrations. At the same time, it was behind lengthy local strikes, to protest against the closure of a great many industrial firms (especially in steel manufacturing, metalworking and the automobile sector), in which the CGT had a strong presence. These strike actions had also political reasons. Indeed, the turn to austerity adopted in 1984 led to departure of Communist ministers appointed to the government in 1981. So, the protests organised had strong political significance: at the same time as the PCF, the CGT switched to a stance of politically opposing the Socialist government, seeking to weaken it through social struggles (Mouriaux, 1998).

2. Martine Gilson, "Edmond Maire: la vieille mythologie syndicale de la grève à vécu", Libération, 29 October 1985. 


\section{The decline and metamorphosis of strike action}

The protest strategy adopted by the CGT was nevertheless insufficient to halt a decline in the intensity of strike action during the 1980s. The number of days not worked due to strike action (DNW) recorded in the 1970s hit record levels in France, as it did in many other Western European countries (Brandl and Traxler, 2010). More than 3 million DNW were recorded in 1975, 1976 and again in 1979. By contrast, in the following years, the number of DNW fell sharply as can be seen in the graph below. From the mid-1980s, it was usually in the range of 250,000 and 500,000 DNW.

The fall in the number of strike days in France in the private sector (JINT)

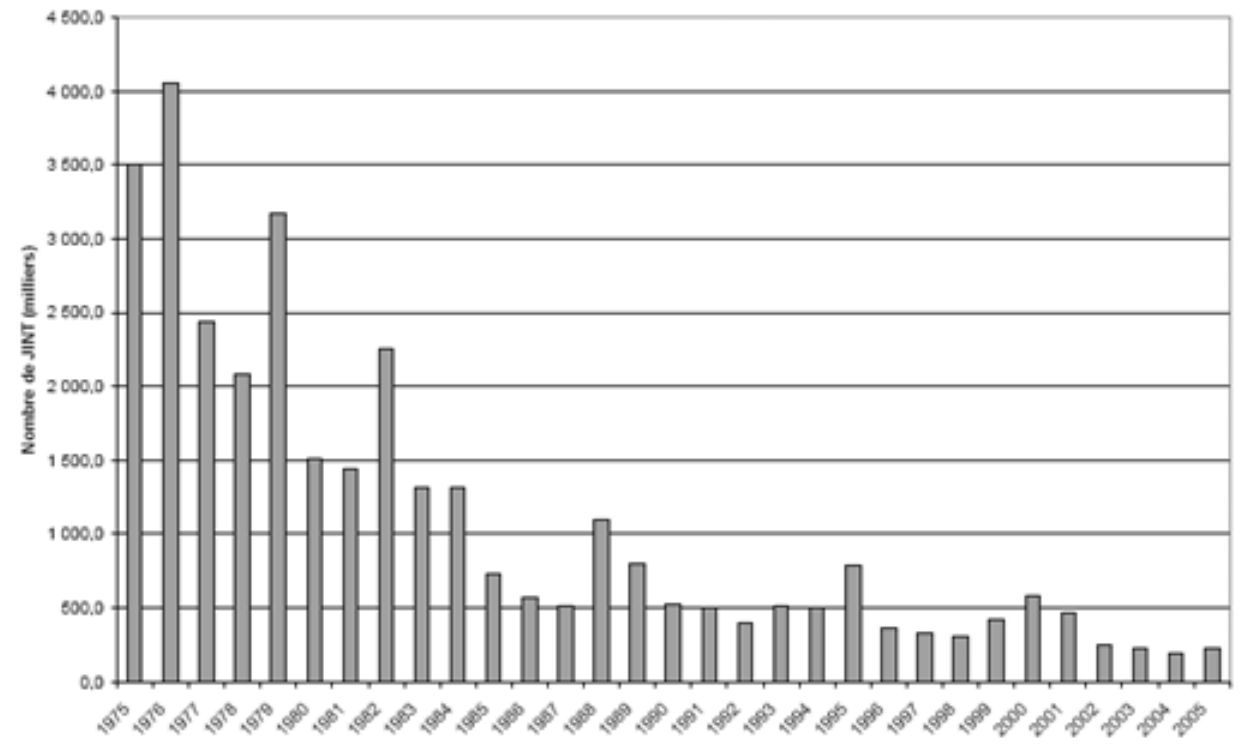

Scope: Private sector and nationalised public companies, 1975-2005, excluding transportation after 1996.

Source: Alexandre Carlier, "Mesurer les grèves dans les entreprises", Documents d'Études de la DARES, n. 139, 2008, n. 34.1.

This tail-off in strike action mirrored a substantial weakening of French trade union organisational and political capacities. At first, the trade unions' political power was hit by the electoral meltdown of the PCF and its rapid retreat to the margins of French politics. French trade unionism also entered into a period of dwindling membership numbers. Membership rates fell to $11 \%$ of the working population, with strong disparities between the private ( $8 \%$ ) and public sectors $(20 \%)$. The fall in union members hit all organisations but especially the CGT, which lost two-thirds 
of its members in just ten years. Isolated both politically and as a union movement then cut adrift from a large part of its activist base, the CGT's ability to muster workers against the neo-liberal policies introduced from the 1980s was seriously hampered.

The drop in the level of industrial action also had economic causes. Just as elsewhere in Europe, the steepest drop in strike activity was in the private sector, due to the radical changes that happened in European economies (Sheuer, 2006). Firstly, the industrial sector has declined, whereas it was the most favourable ground for union action and strikes in the post-war period. Without this anchor point, the unions subsequently struggled to grow their activities in the new sectors of the service economy. As such, the rate of strike action in retail and private sector services still lagged behind those still recorded in industry (Béroud et al., 2008).

Changes to the French production model itself consequently formed another significant obstacle to the growth of trade union action. Firstly, the average size of businesses was falling, leading to a fragmentation of the productive fabric and employment base. Secondly, these businesses tended to be increasingly dependent on large groups, controlled by a financial power much more mobile. All these organisational and economic changes limited the ability of unions to organize mobilizations at a large scale. This was partly due to the extent of union presence and their abilities to trigger strikes being closely linked to company size (Béroud et al.2008). Union action and strike activity is for the most part a feature in large companies, because labour relations are organised more collectively while hierarchical divisions are more pronounced. By contrast, labour relations in small firms are embedded in more personalised and paternalistic relationships of power. These hinder the ability of trade unions to appear as legitimate and useful mediators acting in the employees' interests. Finally, the unions' ability to muster support in the private sector has been hampered by the rise of job insecurity and the growth of lasting mass unemployment, which, as we know, contributes to heightening related risks for employees who might consider strike action.

In the private sector, especially, strikes were not only becoming increasingly rare but also more localised and fragmented (Bordogna and Cella, 2002). The vast majority of strikes in the private sector are limited to the perimeter of a single company. Even in the industry, strike wide strike became much rarer compared to the past. In the same way, the involvement of privately owned company employees in strikes and demonstrations organised at the national level to oppose liberal government and employer policies became very limited. In essence, public sector employees now conducted these protest methods, which became rarer and rarer in the 1980s and 1990s. The fragmentation of strike action in the commercial sector subsequently featured another new difficulty facing trade union organisations. This involved 
their ability to re-register and combine company protests in broader disputes that no longer sought to exert economic pressure on a specific employer but operate as an instrument to challenge the policies of the government and employers' representatives. The splintering of trade union protests in the private sector must clearly be considered in relation to the fragmentation of productive fabric that makes organising and coordinating local union action much more difficult. Yet, it also stemmed from effects linked to decentralised collective bargaining procedures within companies. This process is common to all European industrial relations systems and accompanies liberal labour market reforms. It aims to make collective bargaining procedures as a means of adjusting the rules governing labour relations at the level of establishments (Andolfatto and Contrepois, 2016). The decentralised collective bargaining process has been especially strong in France and directly contributed to the fragmentation of trade union struggles by changing the nature of militant links, within the trade union organizations.

Until 1968, trade unions had no legal existence within companies. That's why trade unionist activities were mainly organised through local trade union institutions, les Bourses du travail and les Unions Locales. These internal trade union organisation arrangements subsequently favoured maintaining regular links between all the union members and in turn made it easier to muster member support around the challenge of common struggles (Shorter and Tilly, 1974). The institutionalisation of trade union representation in companies had the effect of weakening these militant links. Local union representatives first obtained new legal and operational resources (Béroud and Galvão, 2019). French trade unionists are subsequently less dependent on militant resources provided to them by their organizations to fulfil their union brief. At the same time, the growth of collective bargaining with company union representatives led the latter to spend most of their time on tasks representing their union in their establishment. This was especially so given the general climate of weakened trade unionism which tended to convince a lot of grass-roots militants that it was easier to mobilise and hope to win around local issues. Given that institutional and union resources enjoyed by trade unionists in the private sector are far smaller than those provided to their public sector counterparts, the first ones are logically less likely to see inter-professional disputes as major struggles worth getting involved with. In most cases, they prefer to focus their efforts on internal matters, thus contributing to a significant division between local trade union activities and union demonstrations called by central union leaders. 
Between resurgence and ongoing constraints to trade union action (1995-2017)

Despite the waning in their activist roots, trade unions did not, however, lose their power of mobilization. On the contrary, from 1995 to 2010, in a political context marked by a series of neo-liberal welfare system and labour market reforms, France was once again the setting for several waves of large trade union disputes. This resurgence in social conflicts is not specific to France. Over the same period, it can be observed in a large number of European Union Member States, which also brought forward bills to make structural reforms to the labour market and welfare systems. France was nevertheless one of the countries that experienced the largest number of strikes and protests (Gall, 2013). On several occasions, the unions succeed in organizing a series of national strikes and large demonstrations. Some of these attracted several million workers to protest in the streets while renewable strikes sometimes occurred in different professional sectors (railway workers, teaching, refineries). The size of this resurgence in trade union action reveals the resilience of specific traits inherent in labour relations in France. That said, the unions' protest strategies to counter government policies were taking new forms and encountering significant limits. The new fall in trade union action during the 2010s provides evidence of this, all the more so as liberal policies accelerated and further added to this trend during this time.

Boxed text - 1995-2016: Trade Union Protests Against Liberal Reforms

1995: Long strike action (3 weeks) by railway workers and Parisian drivers, as well as national against the financial reform of the social security system and the railway workers' pension scheme. The government wanted to end the possibility for these employees to retire earlier. It was forced to give it up after the protests brought together more than two million people. On the other hand, the social security reform has been adopted.

2003: Ten days of protests organised from January to July against pension reforms proposed by the Raffarin government. This law extends to the public sector the pension reform initiated in the private sector in 1993. In particular, it provides for an increase in the number of working years required for retirement. More than one million protesters in early June and long strike action in the state education system. 2006: French high school students' unions and all staff organisations arranged several days of strike action to protest against the "First Employment Contract Scheme" facilitating redundancy arrangements for young employees. 1-3 million protesters recorded. 
2009: 4 days of strikes and protests against austerity policies adopted to address the financial crisis. The largest protests attracted 1 to 3 million employees.

2010: 11 days of strikes and protests organised between 27 May and 23 November to oppose the rise in retirement age. Claims of 3.5 million demonstrators on 12 October, renewable strikes commence at the SNCF and oil refineries.

2016: Demonstrations against the reform of the French Labour Code and collective bargaining procedures ("the Labour Act"), intended to facilitate redundancy procedures and employment flexibility agreements. An online petition gathered 1.5 million signatures.

2019: new wave of strikes and mass demonstrations against a government plan to reform the pension system, accused to encourage the implementation of a private pension system.

\section{Disputes displaying a still-limited political influence of the unions}

In a European context driven with quite similar liberally inspired policies, the range of national institutional and political circumstances framing trade union action constitutes a chief explanatory factor that is key to the diversity of strike activity intensity observed in various European Union Member States (Kelly et al., 2013). Indeed, he propensity of trade unionists to use strike weapon partly varies with the institutional and political resources they can muster in the political exchange process with the State and the employers (Pizzorno, 1978). However, in contrast to so-called neo-corporatist models (especially in the Scandinavian countries and Austria) in which trade union organisations are strongly embedded in the political decision-making process (Korpi and Shalev, 1980), French trade unions still have very limited power to influence political decision-making processes (Kelly et al., 2013).

Clearly, trade union representatives now have regular dialogue with the State but they are still very much subordinate in terms of political power. Firstly, despite the grow th of collective bargaining procedures, the French State still plays a central role in determining the rules governing social models (Howell, 2009). In other countries, the principle of independent decision-making in collective bargaining between employers and unions continues to impose the conditions for government interventions in social and economic matters. On the contrary, French governments constantly threatened to bypass any eventual opposition from trade unions to reforms by passing legislation ignoring their opinions. This political pressure contributed to forcing trade unions to accept to negotiate the implementation of neoliberal reforms that 
the government wanted to adopt in return for the promise of a few concessions. In doing so, they also avoided having their institutional position challenged together with the related benefits (organisational, financial and symbolic) they enjoyed. French trade union leaders are also suffering from the weakness of their relays in the central administration, and the dwindling of their links with Left-wing parties (Howell and Daley, 1992). The collapse of the PCF plus the distancing of relations between the PS and CFDT meant that backing from supporters and institutional bodies that could be mustered by the unions had never been at such low levels. As such, there are now very few trade union leaders among Ministerial officials, including in Left-Wing governments. The very limited institutional and partisan resources that French trade unions can activate in the political field why the use of collective action still occupies a central role in the implementation of trade union action strategies to try and change the outcome of consultation procedures that the unions frequently criticise for their formal nature.

\section{Variable trade union alliance processes}

As we have seen, French trade union leaders were nonetheless split in the way they view striking and neoliberal policies. As such, during a series of disputes in 1995 and 2003, the CFDT managers decided (with the CFTC) to not take part in the protests started by other trade union organisations. In addition to its 'reformist' switch, the management of the CFDT agreed to support ongoing government welfare reforms, primarily as it deemed these reforms necessary to support a competitive French economy. The CFDT also justified its involvement in negotiations as a way of obliging the government to make concessions in return for securing the support of some trade unions and thus give additional legitimacy to the reforms undertaken. The CFDT, for example, went on to secure an agreement that successive measures to extend the age of retirement were coupled with greater recognition for the arduous nature of work and the length of working careers when calculating retirement age and pension amounts paid out. The choice made by the CFDT leaders in these negotiations can be explained by the benefits it hoped to secure in a competitive French trade union environment. At first, this was actually the means to strengthen its position as first interlocutor of the Employers and the State. It also hoped to boost its credibility in the eyes of employees by appearing to be able to reconcile a pragmatic approach for economic problems with defending the interests of the most vulnerable sections of the workforce by securing new rights for them. On the other hand, it blamed its competing trade unions of taking pleasure in adopting a purely dissenting position and defending the continuation of a welfare system that had failed to halt growing 
inequalities between employees on the labour market and in access to social rights (unemployment benefit and pensions, in particular).

Nevertheless, trade union alliances and divisions in the face of neo-liberal reforms vary according economic and political circumstances. Indeed, all the unions joined forces against the government in 2006,2009 and 2010. The meeting of trade union minds is relatively rare in France and can best explain the strength and length of union protests in 2009 and 2010. In 2006, the trade union alliance came about by the weight of mass protests by students and high-school pupils who teamed up to oppose a reform that threatened to undermine the conditions of their joining the labour market. The sheer numbers of young demonstrators caused the bill to be abandoned and encouraged all trade unions to support and seize this dispute to protest against a more general loosening of the rules on redundancies. Following on from this successful, all the trade unions came together again in 2009 and 2010 to organize numerous strikes and demonstrations. Given the surge in company restructures caused by the outbreak of the economic and financial crisis of 2008, trade union divisions faded away behind a series of demands focusing on defending social rights, purchasing power and regulating the financial sector to protect workers.

In these two periods of protest, the united front of the unions was based primarily on challenges related to labour market reform and defending the most vulnerable employees. These challenges were less divisive for the unions compared to those linked to welfare reform. The trade union coalition was also formed as a reaction to the temptation of the governments concerned to prevent all trade unions from having any input to their decision-making processes. In 2006, for example, the Prime Minister, Dominique De Villepin, totally bypassed trade union leaders, who learned of the existence of his bill through the press. Elected French President in 2007, Nicolas Sarkozy took a highly vindictive attitude towards the trade unions that he described as archaic counter-powers that were barely representative and had little authority. From the first months of his term, he championed a bill to place more restrictions on the right to strike for workers in the public transport sector. The radical position adopted by the new President made it easier for employees' organisations to join forces since it resulted in marginalising even the so-called 'reformist' trade unions that were unable to justify their action in the field of negotiation that the government refused to engage in (Béroud and Yon, 2012).

\section{The organisational factors of the mobilising paradoxical power of French trade unionism}

As the theory of collective action suggests (Tilly, 1984), union strategies take different forms according to the balance between government strategies, organisational 
resources that trade union leaders possess and the familiarity they maintain with collective action weapons. As such, the scale of trade union mobilisation in the 2000s might come as a surprise given the low membership numbers. This apparent paradox firstly stems from the profile of union leaders (national and local) from the three main central trade unions that were key to rallying member support (in descending order, the CGT, the teachers union, the FSU ${ }^{3}$, and Sud-Solidaires to a lesser extent). These three organisations are part of a strand of French trade unionism marked by its historic proximity to Left wing parties, especially the Communist Party and the Trotskyite Far-Left. Clearly, these connections are now weaker and the leaders of these trade unions are currently united behind the principle of union action independent from political parties. There is nevertheless plenty of exchange between these activist spheres at union management levels (Giraud et al., 2018). Many of union officials inherited a Left-Wing political socialisation and, as such, remain very much imbued with an anti-liberal militant ethos that is still focused on a highly Marxist vision of labour relations. Finally, these unions official are recruited among grass roots militants. For this reason also, the organisation of strikes and protests is part of the militant practices with they are particularly familiar (Giraud, 2009).

The leaders of these trade unions also retain a genuine power to drum up support in the public sector. Trade union membership rates have stayed at around 20\% in the public sector, with most CGT, FSU and Sud-Solidaires members coming from public administrations and companies. This bastion of unionism stems primarily from the employment protection status afforded to civil servants, which makes union membership and strike action less risky. In addition, the status of civil servants centres on a strong professional identity in conjunction with collective rules to manage jobs and wages, helping to establish more coherent professional groups that are easier to mobilise. To achieve this, trade unions can call on institutional resources that are far greater than those enjoyed by their private sector counterparts. Trade union representatives in the civil service are, for example, directly linked to managing the careers of civil servants. As such, they more easily position themselves as possible sources of help for civil servants to resolve their problems. Finally, trade unions in the public sector enjoy access to greater financial resources and a larger number of permanent staff indirectly funded by the State (Giraud et al., 2018).

The activist and organisational roots of these trade unions in the public sector formed an even stronger platform to trigger disputes in the 2000s than plans to reform the welfare system especially affected public sector workers. Indeed, one of the main aims stated by the governments was challenging special welfare benefits

3. FSU: Fédération Syndicale Unitaire 
enjoying public sector workers (taking retirement especially) to bring them into line with private sector employees. In a public sector threatened by numerous reforms (liberalisation, decentralisation) generating social tension, the widespread involvement of its employees in national protests proceeded from a mixed of grievances. These were a combination of general opposition to government policies and defending the corporation's own rights. In 1995, as in 2010, the French railway workers were central to opposing governmental reforms as they sought, in particular, to challenge the special pension system that railway workers benefited from. Similarly, in 2003, protests against plans to reform the French pension system were also based on the involvement of teachers who took part in a long protest movement. This primarily sought to oppose the government's decision to allocate part of the non-teaching staff from the French education system to the regional councils: this measure was seen by the protesters as the thin end of the wedge in contesting the status of these public sector workers.

Finally, these mass protests in the 2000s are linked to a wider resurgence in conflicting relations in the workplace. While European surveys indicate that the fall in strike action continued in the 2000s (Vandaele, 2016), the French data on labour conflicts reveal that the proportion of French establishments that experienced collective disputes, with or without work stoppages, actually rose considerably at the start of the 2000s (by 10 points) then settled down until the end of the decade (Giraud and Marcelino, 2019). From an economic theory standpoint, this surge in strikes can be put down to a return to economic growth in the early 2000s, which coincided with a sharp decline in unemployment (Coutrot, 2001). Conversely, between 2008 and 2010, the economic downturn did not trigger an immediate drop in strike action. It can even be seen that strikes actually rose in establishments faced with a fall in business and plans to restructure. In other words, the tensions generated by the economic downturn contributed, at least initially, to creating conflicts that encouraged trade union leaders to prolong and step them up by organising national demonstrations when the spectre of new austerity policies appeared.

\section{Persistent limits on union mobilization power}

This revival in trade union protests has nevertheless declined sharply in the last few years. It is symptomatic of the limits of union mobilization power, which were already visible in the protests that took place in the 2000s. This protest activity firstly showed the limits that the trade union leaders, even those tagged as "dissenters", set themselves in the use of strike weapon to challenge government policy. Throughout these various periods of protest, the leaders of the CGT refused, in particular, to 
call a renewable general strike, even when the processions of demonstrators had attracted several million workers. The refusal to engage in a strategy to radicalise trade union mobilisation can be explained by the separation that the leaders of the CGT now perceived necessary to maintain between strategies of trade union campaigns and partisan struggles. Obviously, organising strike action and mass protests is still an instrument of political struggle used by trade unions to exert pressure on the government (Gall, 2013). That said, trade union leaders in general are still wary of maintaining their activities within the field of collective bargaining, with the sole aim of voicing their demands more effectively to the government. As a result, trade union leaders want to retain their authority as spokespersons for mobilising employees and above all avoid being dispossessed in favour of other stakeholders, especially political participants. Therefore, the prospect of calling a renewable general strike is likely to create a situation of political crisis that may give the opposition parties a key role rather than trade union organisations (Giraud, 2006).

Furthermore, the shape and form of these large-scale union demonstrations reflects the difficulties encountered by union leaders to encourage private sector workers' mobilization. Throughout the decade, their participation in the mass demonstrations of, and even more in the strikes, remains very limited. The gap in participation between private and public sector employees undermines the legitimacy of these trade union rallies, often denounced by the press and political leaders as just "privileged" employees protesting. This situation deepens union leaders' hesitations to opt for more radical strategies that would risk making the participation of private sector employees even more difficult (Giraud, 2006). Finally, the unions have widely failed, with the exception of 2006, to secure the withdrawal of controversial government plans or genuine consideration for their demands for new social rights for employees vulnerable to job insecurity.

The outcome of this cycle of protests is one aspect that explains, along with others, the further decline in the intensity of labour disputes since 2010, whereas liberal reforms to welfare and the labour market have been on the rise under the Presidencies of F. Hollande (Socialist Party) in 2012, then E. Macron in 2017. Clearly, the El Khomri Act (2016), which introduced new flexible employment measures and a far-reaching review of collective bargaining rules triggered new resistances ${ }^{4}$. A petition was launched on social networks outside all official trade union channels. It quickly secured more than one million signatures, consequently encouraging

4. Inspired by the recommendations of the European Commission and other reforms undertaken in European Union countries, the bill is organized around three objectives: to facilitate economic dismissals, to cap the compensation received in case of unfair dismissal and to lower the level of overtime pay. 
union leaders to organise several demonstrations. This time, the protests nevertheless remained on a much smaller scale (Béroud, 2018). Following on, E. Macron undertook even more radical reforms from the start of his Presidential term that didn't manage to spark proper collective protest action until the end of 2019. This social apathy can be explained by a combination of structural and cyclical factors. Firstly, as they were deemed to be failures, the experience of protests in the 2010s was able, at least temporarily, to amplify the difficulties trade unions had in mustering support considering that it stoked the feeling among employees that strike action and demonstrations were ineffective forms of action to reverse governmental decisions. At the same time, the public sector endured the introduction of managerial policies directly imported from the private sector (widespread growth of unstable employment contracts ${ }^{5}$, individual wage and career policies). This gradually undermined the potential of trade union protest action.

Finally, political changes that have taken place at the government level during the 2010's have also contributed to the slowing down of social conflict. The François Hollande's mandate seems to provide proof that the presence of a Left-Wing government hinders the growth of collective protest action, independently of the way in which they involve trade unions in their decisions (Brandl and Traxler, 2010). Firstly, maintaining a special relationship between leaders of the PS and CFDT helps understand that this main trade union body prefers to stand out from other unions to yet again focus on looking for a compromise to implementing reforms. Secondly, it is more difficult for trade union organisations to mobilise employees against neo-liberal political reforms when a Left-Wing government introduces them. Trade unions opposed to these reforms actually saw themselves politically isolated when challenging them. They also found it all the more difficult to persuade employees that they could oppose alternative choices to liberal policies defended by the majority and the opposition.

To conclude: A new sequence of neo-liberal reforms and union resistance with president Macron

The current French President, Emmanuel Macron, was elected from outside the major French parties, but is perfectly in line with the liberal policies of his predecessors. Since his unexpected victory, he has pushed up a series of measures to make the mar-

5. The public service is not immune to the development of precarious and flexible employment standards. In recent years, more than half of the staff recruited by the State have been recruited on fixed-term contracts over time (Peyrin, 2019). 
ket of labour more and more flexible. To this end, the process of decentralization of collective bargaining has been significantly amplified. From now on, company-level agreements will most often take precedence over industry-level collective agreements. This gives employers new leeway to increase the flexibility of their employees and reduce wages. These laws also provide for the possibility, based on the German model, of negotiating "competitiveness" agreements, whereby employees are asked to accept a reduction in their pay and an increase in their working time in exchange for maintaining their jobs. At the same time, finally, the number of employee representatives in companies has been reduced by a third, and the powers and means of action of trade unionists have been severely curtailed. French trade unionism thus appears more than ever to be weakened and its legitimacy called into question, with President Macron distinguishing himself by his willingness to denigrate trade unions and all intermediary bodies. The trade unions appeared totally powerless to challenge in any way the policies implemented by President Macron during his first two years in office. In particular, they have totally failed to mobilise employees against a highly contested unemployment insurance reform voted in spring $2019^{6}$.

Until 2019, the protest movement that has most disrupted the new government did not emerge from trade union (and partisan) organisations. The "Gilets Jaunes" (yellow vests) movement initially grew as a reaction to a rise in fuel prices before extending to cover more conventional social demands linked, in particular, to purchasing power. This mobilization brought together individuals who had hitherto had little experience of mobilization, often in precarious situations on the labour market or working in small businesses, without contact with trade unions. The trade union leaders have stayed at the margins of this protest movement and have failed to expand it in companies and administrations. They have found their ability directly challenged, not only to resist the raft of liberal reforms but also to convey the social demands of the most downtrodden segments of workers.

Trade unions, however, do not (yet) belong to the "old world" that President Macron claims to be disappearing. Indeed, the latest reform of the pension system, discussed at the time this article is written, is once again provoking a great deal of trade union mobilization. Demonstrations have brought together more than a million workers, and Parisian train and metro drivers have been on strike for more than a month. A record since the strikes in 1995 in the same two sectors. In spite of the unexpected intensity of these strikes, they have failed - at the time of writing - to

6. For example, a few months before the reform of the pension system, all the French trade unions contested a reform of the unemployment insurance system that reduces benefits, introduces degressivity of benefits and shortens the duration of benefits. But they were unable to mobilize to prevent its adoption by the French parliament. 
secure withdrawal of the reform. In fact, this latest protest movement has followed the same pattern of mobilization as in the past: strike action is remained mainly concentrated in the public service or in strategic economic sectors (transport, ports, energy). Even if public opinion is overwhelmingly supportive of the strikers, this sympathy does not translate into a wider participation of the different segments of the workforce in the mass demonstrations. This protest demonstrates that the capacity of French trade unions to use strikes and demonstrations as an instrument of political pressure remains hampered by the transformations of the French economy. Not only because it is more difficult to block the French economy in the context of a globalized economy. But also because it remains difficult to envisage the possibility or advisability of committing to these forms of action for many employees, particularly those who are most in a precarious situation on the labour market. It is therefore difficult to oppose, through mobilization, the reforms that affect the most precarious employees. Thus, through its ability to mobilise the most stabilised fractions of the workforce, French trade unions have been able to slow down the introduction of neo-liberal reforms, in comparison with many other EU countries. Thus, through its ability to mobilise the most stabilised fractions of the workforce, French trade unions have been able to slow down the introduction of neo-liberal reforms, in comparison with many other EU countries. But it is not enough to prevent the development of precarious work, the segmentation of labour market, and the gradual calling into question of the social protection system, which until then had been recognised as one of the most protective in the world.

\section{References}

Andolfatto, Dominique \& Contrepors, Sylvie. (2016), Syndicats et dialogue social. Les modèles syndicaux à l'épreuve. Bruxelles, Peter Lang.

BÉroud, Sophie et al. (2008), La lutte continue? Les conflits du travail en France, Bellecombeen-Bauge, Editions du Croquant.

BÉroud, Sophie \& Yon, Karel. (2012), "Face à la crise, la mobilisation sociale et ses limites: une analyse des contradictions syndicales”. Modern \& Contemporary France, 20 (2): 169-183.

BÉroud, Sophie. (2018), "French trade unions and the mobilization against the El Khomri law". Transfer, 24 (2): 179-193.

Beroud, Sophie \& Galvão, Andrea. (2019), "Dinâmicas do sindicalismo: entre institucionalização e recomposição”. In: GALVÃo, Andrea et al. (org.). O Brasil e a França na mundialização neoliberal: mudanças políticas e contestaçôes sociais. São Paulo, Alameda, vol. 1, pp. 221-259.

Bordogna, Lorenzo \& Cella, Gian-Primo. (2002), "Decline or Transformation? Change in Industrial Conflicts and its Challenges". Transfer, 8 (4): 585-607. 
Brandl, Bernd \& Traxler, Franz. (2010), "Labour Conflicts: A Cross-national Analysis of Econmic and Institutionnal Determinants. 1971-2002”. European Sociological Review, 26 (5): 519-540.

Coutrot, Thomas. (2001), “Une nouvelle période pour la conflictualité sociale?”. Les Cabiers Français, 304: 46-51.

Franzosi, Roberto. (1995), The puzzle of strikes: class and state strategies in postwar Italy. Cambridge, Cambridge University Press.

GALL, Gregor. (2013), "Quiescence continued? Recent strike activity in nine Wester Euopean économies". Economic and Industrial Democracy, 34 (4): 667-691.

Giraud, Baptiste. (2006), "Au-delà du déclin: difficultés, rationalisation et réinvention du recours à la grève dans les stratégies confédérales des syndicats". Revue Française de Science Politique, 56 (6): 943-968.

Giraud, Baptiste. (2009), Faire la grève: les conditions d'appropriation de la grève dans les conflits du travail en France. Paris, thèse pour le doctorat de science politique, Université Paris 1.

Giraud, Baptiste et al. (2018), Sociologie politique du syndicalisme, Paris, Armand Colin.

Giraud, Baptiste \& MarCElino, Paula. (2019), "Análise comparada de greves na França e no Brasil nos anos 2003". In: Boufartigue, Paul et al. (orgs.). A França e o Brasil na mundialização neoliberal: mudanças políticas e contestações sociais. São Paulo, Alameda, pp. 203-238.

Groux, Guy \& Mouriaux, René. (1989), La CFDt. Paris, Economica.

Howell Chris \& Daley, Anthony. (1992), "Introduction: the transformation of political exchange". International Journal of Political Economy, 22 (4): 3-16.

Howell, Chris. (2009), "The transformation of French industrial relations: labor representation and the State in a post-dirigiste era”. Politics and Society, 37 (2): 229-256.

Kelly, John et al. (2013), "Unions against goverments: explainig general strikes in Western Europe, 1980-2006”. Comparative Political Studies, 49 (6): 1030-1057.

Korpi, Walter \& Shalev, Michael. (1980), “Strikes, power, and politics in Western Nations, 1900-1976". Political Power and Social Theory, 1: 301-334.

Mouriaux, René. (1998), Crises du syndicalisme français. Paris, Montchrestien.

Peyrin, Aurélie. (2019), "Les recompositions des normes d'emploi public". Revue Française de Socio-Économie, 22: 67-84

Pizzorno, Alessandro. (1978), "Political exchange and collective identity in industrial conflicts", In: CROUCH, Peter et al. (org.), The résurgence of class conflict in western Europe since 1968. London, Palgrave Macmilan, pp. 277-298.

Rioufreyt, Thibault. (2019), "Muito faladas, diversamente mobilizadas: as classes médias na França dos anos 1990-2015”. In: GALVÃo, Andréia et al. (orgs.). O Brasil e a França na mundialização neoliberal: mudanças políticas e contestaçôes sociais. São Paulo, Alameda, pp. 59-77.

SHEUER, Steen (2006), "A novel calculus? Institutional change, globalization and industrial conflict in Europe", European Journal of Industrial Relations, 12 (2): 143-165. 
Signoretto, Camille. (2015), "Restructurations, gestion de l'emploi et droit du travail: analyse institutionnelle et statistique". La Revue de l'IRES, 84: 31-58.

Shorter, Edward \& Tilly Charles. (1974), Strikes in France 1830-1968. Cambridge, Cambridge University Press.

Tilly, Charles. (1984), “Les origines du répertoire de l'action collective en France et en GrandeBretagne”. Vingtième Siècle, 4: 89-108.

VANDAELE, Kurt. (2016), "Interpreting strike activity in Western Europe in the past 20 years: the labour repertoire Under pressure”. Transfer, 22 (3): 277-294.

\section{Abstract}

The changing face of union action put to test by neo-liberals reforms in France

This article reviews how French trade union are coping with the neo-liberal policies since the early 1980s. It shows their divergent reactions, and how these liberal reforms are implemented in a context of transformation of trade union action: the use of strikes is more difficult at the same time as the relationship between trade unions and collective bargaining is transformed in a logic of depoliticizing their strategies of action. These developments did not prevent a resurgence of strikes in the 2000s. It reveals the limits of the trade unions' power of political influence, that implies the use of collective action. However, strikes have declined further in recent years, revealing the weakening of trade union mobilisation power.

Keywords: Strikes; French Trude Unionism; Collective bargaining; Neo-liberalism; Contentious politics.

\section{Resumo}

A recomposição da ação sindical na França em um contexto de reformas liberais

O artigo examina como o sindicalismo francês enfrenta, desde o início dos anos de 1980, as políticas neo-liberais. Identificamos suas reações divergentes e como as reformas neo-liberais são implementadas em um contexto de transformação da ação sindical: o uso das greves é mais difícil e a relação entre os sindicatos e a negociação coletiva é transformada em uma lógica que despolitiza suas estratégias de ação. Esses desenvolvimentos, porém, não impediram o ressurgimento das greves nos anos 2000. O artigo revela ainda os limites da força de influência política dos sindicatos, que implica o uso da ação coletiva. Nos últimos anos, as greves declinaram, revelando o enfraquecimento do poder de mobilização dos sindicatos.

Palavras-chave: Greves; Sindicalismo francês; Negociação coletiva; Neoliberalismo; Confronto político. 
Texto recebido em 12/11/2019 e aprovado em 6/1/2020.

DOI: 10.11606/0103-2070.ts.2020.164063.

BAPTISTE GIRAUD is professor in political science at Aix-Marseille University and a member of the Laboratoire d'Economie et de Sociologie du Travail (LEST, UMR 7317). Using statistical and qualitative survey methods, his research focuses on the dynamics of labour conflicts and industrial relations in France. With Karel Yon and Sophie Béroud, he is the author of a book on the contemporary transformations of trade unionism in France: Sociologie politique du syndicalisme (2018).E-mail: baptiste.giraud@univ-amu.fr.

(c) (1) ( 